\title{
The Effect of STAD Cooperative Learning Model and Critical Thinking Ability on Learning Outcomes PPKn Grade V Students of SD Negeri 060934 Medan Johor
}

\author{
Romaida Karo Karo ${ }^{1}$, Reh Bungana Br Perangin-angin ${ }^{2}$, Abdul Murad \\ 1,2,3 Postgraduate Basic Education, Medan State University, Indonesia \\ romaida288@gmail.com
}

\begin{abstract}
This study aims to determine the differences in student learning outcomes taught by the cooperative learning model type STAD and conventional teaching, to find out the differences in the learning outcomes of PPKn students who have higher critical thinking skills compared to students who have low critical thinking skills, and to find out whether there is an interaction between the STAD type cooperative learning model with critical thinking skills on the learning outcomes of PPKn grade $V$ students of SD Negeri 060934 Medan Johor. This research was conducted at SD Negeri 060934 Medan Johor. The research sample was determined by cluster random sampling, one class as an experimental class was taught with a STAD type cooperative learning model and one control class was taught conventionally. The sample to be studied amounted to 52 students consisting of 25 experimental class students and 27 control class students. Critical thinking ability tests are conducted to classify students who have high critical thinking skills and low critical thinking skills. Data were analyzed using two-way ANAVA using statistical tests with factorial design of $2 \times 2$ ANAVA with a significance level of $>0.05$. Previously performed the normality test and homogeneity test analysis. The results showed that the learning outcomes taught using the STAD type cooperative learning model are better than conventional learning models in improving PKn learning outcomes of students as well as students who have high critical thinking skills who obtain better learning outcomes than students who have low critical thinking skills.
\end{abstract}

Keywords

STAD cooperative learning model type; critical thinking;

\section{Introduction}

Learning Outcomes are abilities possessed by students after they have received their learning experiences, namely skills and habits, knowledge and understanding, attitudes and ideals, behavior, as learning outcomes can be seen from the knowledge, attitudes, and skills possessed by students, results learning can make students very enthusiastic in learning.

A teacher will know the level of success of students in learning. The level of ability of students in teaching and learning can be known from the results of learning. From these learning outcomes the teacher will obtain grades and illustrate the level of student success in learning from the material that has been learned.

Factors that influence learning of many types but can be classified into two groups, namely factors from within students themselves (internal), and factors from outside students themselves (external), Slameto (2010: 54). Internal factors usually originate from within students namely physiological and psychological students, sometimes found students 
who are very active and there are students who are quiet, not least also found students who have low motivation in learning, all of which will affect the learning process in the classroom. External factors usually originating from outside oneself are the community, teacher and school environment (Sanjaya 2011: 52).

According to Rangkuti (2019) Education is a very fundamental human phenomenon and also has constructive traits in human life. That's why we are required to be able to hold a scientific reflection on education, as a responsibility for the actions taken, namely educating and being educated. Citizenship education is part of education in shaping human nature. Character or character can only be formed and developed through the educational process, not by teaching. Pancasila and Citizenship Education subjects need to be delivered to all students ranging from elementary school to high school to equip students with social skills so that students have moral, character in the midst of society (Panggabean, 2019). According to Setiawan (2014: 3) "character education is the process of giving demands to students to become fully human beings who have character in the dimensions of heart, mind, body, and taste and intention". Therefore, students are trained to be able to play an active role in learning so that one day when they enter the community, they can express their opinions and provide ideas that are useful for many people. So students will become smart, participatory Indonesian citizens and become responsible citizens. Citizens have the fundamental goal to move the life of democracy following the state of the social-political environment. The involvement of citizens as the subject of democracy will give birth to a strong citizen character (Mukmin, 2019).

One way to improve student learning outcomes is by increasing students' critical thinking skills in learning. According to Scriven (Walker, 2006) critical thinking as an intellectual process in making concepts, applying, analyzing, observing, experiencing, reflecting, where the results of this process are used as a basis for taking action. In critical thinking can be seen by the teacher by providing material where the subject matter is taught with the learning model through small groups. By learning through small groups, the teacher will provide students independently to think about the material and see to what extent students develop the material taught by the teacher.

By using the STAD type Cooperative learning model, knowledge and thought patterns will generally develop, students will be able to create the ideas of each group member in learning. So that students' critical thinking patterns will develop and learning will be easier to understand.

Therefore, learning in the form of collaboration in learning is very helpful in learning. One of the education directs humans to a better life that involves the degree of humanity so as to achieve his life goals in accordance with the origin of the incident. Unlike the case with normal or conventional education, where learning is only the teacher as a facilitator. So that learning is only passive and there is nothing students can take from learning to confuse and boring students in learning. This lecture method cannot make students easy to understand learning because it only focuses on one direction only so that the talents or abilities, interests and attitudes possessed by students will not be seen clearly and cannot be developed.

To realize PPKn learning that makes students a good citizen, the teaching staff or teacher must be able to apply the PPKn subject matter with an appropriate learning model. One that is appropriate is to apply the STAD type Cooperative learning model. By using the STAD Cooperative learning model the PPKn lessons will be more interesting because it can make students learn independently, be creative, think critically, and establish communication between students and teachers and learning more effectively.

In general, when learning in class students are placed as learning objects that only act as recipients of the material delivered by the teacher. However, by using the Cooperative 
Learning model, students who were previously passive and not interested in the material presented will be enthusiastic, skilled, and brave to express their opinions independently and in groups. The purpose of this study are: 1) to find out the differences in learning outcomes of students taught with the STAD type cooperative learning model and conventional teaching on learning outcomes of PPKn grade V students of SD Negeri 060934 Medan Johor. 2) To find out the differences in learning outcomes of PPKn students who have high level critical thinking skills compared to students who have low critical thinking skills in fifth grade students of SD Negeri 060934 Medan Johor. 3) To find out whether there is an interaction between the STAD type cooperative learning model and the ability to think critically on the learning outcomes of PPKn grade V students of SD Negeri 060934 Medan Johor.

\section{Review of Literature}

\subsection{Cooperative Learning Model Type STAD Learning}

Teaching and learning can be carried out using learning models. The learning model applied for now for schools using the cooperative learning model in the form of small groups. Cooperative learning model learning is a learning model that is formed in small groups consisting of 4-5 members of the group.

Shoimin (2018: 45) argues that Cooperative Learning is a learning activity in groups to work together to help each other construct concepts and solve problems. Cooperative Learning does not have to be the same from various family statuses or mindset of each other.

Hamruni (2011: 119) cooperative learning strategies are a series of learning activities carried out by students in certain groups to achieve the learning objectives that have been formulated. According to Hamruni (2011: 130) the limitations possessed in the use of cooperative learning are (a) to understand it takes time; (b) students learn from each other; (c) assessments given are based on group learning outcomes; (d) success in this model requires a long period of time; (e) although the ability to work together is a very important ability for individual students.

Through the cooperative learning model used in this study is the Student Team Achievement Divisions (STAD) Learning model. The STAD learning model was developed by Robert Slavin and his friends at Jhon Hopkin University. According to Slavin (2010: 143) STAD is one of the simplest cooperative learning methods, and is the best model for beginners for teachers who are new to using a cooperative approach.

In STAD type cooperative learning the teacher does not allow students to learn in groups but the teacher has a function as a facilitator and provides direction so that learning in group form can be achieved as expected.

The steps that can be taken in learning by using the STAD cooperative type are: 1) Delivery of Objectives and Motivation. Deliver the learning objectives to be achieved in these learning and motivate students to learn; 2) Division of Groups. Students are divided into several groups, each group consisting of 4-5 students who prioritize class heterogeneity (diversity) in academic achievement, gender / gender and race; 3) Presentation from the Teacher. The teacher presents the lesson material by first explaining the purpose of the lesson to be achieved at the meeting and the importance of the subject being studied. The teacher can also motivate students. In the classroom the teacher is also assisted by media which are usually used in daily life; 4) Learning Activities in Teams (Team Work). The teacher prepares a worksheet as a guide for group work, so that all members master and each one contributes. Students discuss the answers to the teacher's questions with friends in one study group; 5) Quiz (Evaluation). The teacher evaluates the learning outcomes through giving a quiz about the material being studied and also evaluates the presentation of the work of each 
group; 6) Team Achievement Awards. After the quiz, the teacher checks the student's work and is given a number with a range of 0-100. The awarding of group success can be done by the teacher by finding ways to appreciate both the efforts and the results of individual and group learning.

\subsection{Critical Thinking Ability}

Thinking is a mental activity that involves the work of the brain. As every human being must have a left and right hemisphere of the brain, between critical thinking with creative thinking should not need to be dichotomized. In thinking using cognitive methods. According to Vincent in Jhonson (2012: 187) think of it as all activities that help formulate or solve problems, make decisions, or fulfill a desire to understand. The ability to think critically includes clarity, accuracy, relevance, depth, consistency, logic, compatibility, and significance.

According to Surip (2017: 11) critical thinking is a synonym for decision making, strategic planning, scientific process, and problem solving. In thinking the main goal is to gain knowledge, understanding and get new things or ideas and find solutions or solutions to the problems encountered. In thinking one's abilities can be seen from the level of analyzing, criticizing and making conclusions. Different levels of human thinking, there are those who think low level, think basic, think and think high level. Where in that case everything really needs to be developed for the advancement of human knowledge and human future.

Thinking at various levels that need to be developed allows one to be able to know and apply it. Likewise, the fifth grade elementary school students think level can not be said to think mature but the fifth grade elementary school students are able to think highly. In high thinking can be said to think critically. Where the fifth grade elementary school students can already analyze, understand and observe a lesson. According to Sani (2019: 41) the ability to think basic or low level (lower order thinking) only uses abilities that are mechanical and limited to routine things, for example students memorize and repeat information that has been previously known. According to Ennis, 2013 (in the journal Improving Junior High Schools' Critical Thinking Skills Based on Test Three Different Models of Learning critical thinking means reflective thinking that focuses on deciding an action that is believed or something done.

Critical thinking is the use of cognitive skills to increase the likelihood of desired outcomes by someone. Jacob in Firdaus research, et al (2015: 227) states "critical thinking skills will encourage students to think independently and solve problems in school or in the context of every day life". From the above it is explained that the ability to think critically will encourage students to think independently and solve problems in everyday life.

Michael (Fisher, 2009: 10) argues that, "critical thinking is an academic competency that is similar to reading and writing and is almost as important". Therefore, he defines critical thinking as a skilled and active interpretation and evaluation of observation and communication, information, and argumentation.

From the expert opinion above, the essence of critical thinking ability is the ability to think actively looking for various information and sources, then the information is analyzed with the basic knowledge that students have to make conclusions.

According to Ennis (in Maftukhin, 2013: 24), there are five groups of indicators of critical thinking skills, namely as follows:

1. Elementary Clarification. Basic clarification is divided into three indicators namely (1) identifying or formulating questions, (2) analyzing arguments, and (3) asking and answering clarifying questions and or challenging questions. 
2. Give a Reason for a Decision (The Base for The Decision). This stage is divided into two indicators, namely (1) considering the credibility of a source and (2) observing and considering the results of observations.

3. Summing Up (Inference). The concluding phase consists of three indicators (1) making a deduction and considering the results of the deduction, (2) making an induction and considering the results of the induction, and (3) making and considering the value of the decision.

4. Advanced Clarification. This stage is divided into two indicators namely (1) identifying terms and considering definitions and (2) referring to assumptions that are not stated.

5. Supposition and Integration. This stage is divided into two indicators (1) logically consider and think premise, reasons, assumptions, positions, and other proposals that are not approved by them or that make them feel doubtful without making disagreements or doubts disturb their minds, and ( 2) combining the abilities of other abilities and dispositions in making and maintaining a decision.

In critical thinking there are elements of skill as well as in Nasution (2010: 125) elements of thinking skills include: (1) observing; (2) the ability to identify assumptions; (3) the ability to think deductively; (4) the ability for logical interpretation; and (5) the ability to evaluate which arguments are weak and strong.

Critical thinking skills are needed in high-level abilities and must be possessed by students in every learning, especially in this case in learning PPKn. Students can develop their thinking by thinking critically about PPKn subject matter by using the cooperative learning model type Student Team Achievement Divisions (STAD) students can develop their thinking skills by observing, identifying, deductive thinking, the ability to interpret logically and evaluate. Critical thinking does not mean memorizing but understanding and observing and always clings to memories about things or lessons.

According to Sani (2019: 90) critical thinking skills are rather difficult to teach, but students must still be trained to think critically. By doing critical thinking exercises by providing an information in the form of text, and asking students to examine the information by asking a number of questions.

Theories that support the STAD type cooperative learning model are supported by several expert experts so that learning can be achieved. According to Rusman (2013: 386) there is a theory emphasizing behavior or behavior. Pavlov's view lies in the method he uses and the results obtained. In this case the use of a good type of STAD cooperative learning model allows the learning outcomes obtained by students to be good too. Because the teacher conditions the classroom by providing appropriate learning methods will make learning as well as expected and learning outcomes as expected.

While Thorndike views behavior as a response as a response to stimuli in the environment. Stimulus can issue responses which are the starting point of stimulus-response theory or S-R theory. Thorndike argues that if an action is followed by a satisfactory change in the environment, the likelihood that the action is repeated in a similar situation will increase. However, if a behavior is followed by an unsatisfactory change in the environment the likelihood that the behavior is repeated will decrease. So the consequences of a person's behavior at a time plays an important role in determining the person's behavior next. In this case the teacher ensures readiness of students in learning, so that the stimulus provided can be well received by students and bring up the desired response. The stimulus given should often be repeated so that the stimulus response relationship becomes stronger one of them by providing training or emphasis on concepts by the teacher. This relationship can also be strengthened by giving awards to students. 
Skinner suggests another class of operant behavior because this behavior operates on the environment without any unconditioned stimulus. In this case the effect is centered on the relationship between behavior and its consequences. To change this behavior there are pleasant and unpleasant consequences. In this case there is reinforcement and punishment. Strengthening is a consequence that increases the probability that a behavior will occur. Whereas punishment is a consequence that decreases the probability of a behavior occurring. There are types of reinforcement, namely positive reinforcement in the form of rewards and negative reinforcement in the form of adverse or unpleasant, such as showing displeased behavior.

According Dwiyogo (2018: 15) in the theory of learning behaviorism is seen as a change in behavior, where these changes appear in response to various stimuli that come from outside the subject. Response is the response or reaction to a stimulus or stimulus provided. Response is the starting point of stimulus response theory or S-R. According to Watson in Dwiyogo (2018: 18) states that the response resulting from the administration of stimulus must appear in the form of observable behavior (observable). Likewise, to stimulate learning, it is necessary to have learning models that are very suitable to be taught to students. In this case the suitable learning model is the learning model of the Student Team Achievement Divisions (STAD) type of learning model in which this model allows students to respond in learning.

According to Vygotsky students have two different levels of development, namely the level of actual development, which determines the current intellectual function of an individual and his ability to learn for himself certain things, (2) The level of potential development is that which can be activated or achieved by individuals with the help of others, such as teachers, parents or even peers who are smarter, more advanced and more advanced. In this case there are students who have different learning abilities, there are high critical thinking skills and low critical thinking skills of students. Students who have these abilities must be encouraged by parents and teachers to improve intellectually.

\section{Research Methods}

The subjects in this study were all students of class V SD 060934 Medan Johor which consisted of two classes, namely class VA and class VB, amounting to 52 students. The research sample was determined by cluster random sampling of one class as an experimental class that was taught with the cooperative learning model of the STAD type and one class as a control class being taught conventionally. The design of this study uses an experimental research method because this research wants to find out the effect of certain treatments on others (Sugiono: 2009: 34). The instrument data obtained were subsequently used 2x2 factorial ANAVA analysis at 22.00 SPSS.

\section{Discussion}

This research was conducted using $2 \times 2$ factorial ANAVA with the help of SPSS 22.00. The following results are obtained:

Table 1. Factorial ANAVA $2 \times 2$ against Learning Outcomes PPKn

\begin{tabular}{|l|l|l|l|l|c|}
\hline \multicolumn{7}{|c|}{ Tests of Between-Subjects Effects } \\
\hline Dependent Variable: & Learning Outcomes \\
\hline Source & Type III Sum of Squares & df & Mean Square & F & Sig. \\
\hline
\end{tabular}




\begin{tabular}{|l|c|c|c|c|c|}
\hline Corrected Model & $6887,601^{\mathrm{a}}$ & 17 & 405,153 & 6,232 &, 000 \\
\hline Intercept & 142238,368 & 1 & 142238,368 & 2187,811 &, 000 \\
\hline Model & 3005,916 & 10 & 300,592 & 4,623 &, 000 \\
\hline BK & 1001,953 & 1 & 1001,953 & 15,411 &, 000 \\
\hline Model * BK & 422,571 & 6 & 70,429 & 1,083 &, 019 \\
\hline Error & 2210,476 & 34 & 65,014 & & \\
\hline Total & 262500,000 & 52 & & & \\
\hline Corrected Total & 9098,077 & 51 & & \\
\hline a. R Squared =,757 (Adjusted R Squared =,636) \\
\hline
\end{tabular}

1. There are Differences in Student Learning Outcomes PPKn Taught by the Model STAD Type Cooperative Learning Is Higher than Using Conventional Learning.

Based on table 1 regarding $2 \times 2$ factorial ANAVA on the learning outcomes of PPKn with the help of the application of SPSS 22.0 where the learning model obtained a significance value $<0.05$ then the calculation $\mathrm{Ho}$ is rejected and $\mathrm{Ha}$ is accepted. So, from the $2 \times 2$ factorial ANAVA results it was concluded that the learning outcomes taught using the STAD type cooperative learning model are higher than the learning outcomes of PPKn students who use conventional learning models.

2. There is a Difference in Learning Outcomes of PPKn Students who Have Higher Critical Thinking Abilities are Better than Students who Have Low Critical Thinking.

From table 1 on high critical thinking skills and low critical thinking skills is where the learning model obtained a significance value $<0.05$ then the calculation Ho is rejected and $\mathrm{Ha}$ is accepted. So, from the $2 \times 2$ factorial ANAVA results above, it was concluded that student learning outcomes in students 'critical thinking skills taught by learning STAD type cooperative learning models were higher than students' critical thinking abilities taught by learning that obtained conventional learning.

3. There is an Interaction between the STAD Type Cooperative Learning Model and the Critical Thinking Ability of Student Learning Outcomes.

Based on table 1 above about $2 \times 2$ factorial ANAVA where the learning model and critical thinking skills obtained significance value of significance value of 0.19 or significance level $<0.05$ then the calculation Ho is rejected and Ha is accepted. So, from the 2 $\times 2$ factorial ANAVA results it was concluded that there was an interaction between the STAD type cooperative learning model and the ability to think critically on student learning outcomes of PPKn.

\section{Conclusion}

The conclusion that can be made from the results and discussion is that there is an interaction between the STAD type cooperative learning model with the ability to think critically on student learning outcomes. The ability to think critically is a high level ability that allows students to analyze arguments, create skills and develop their thoughts and make conclusions that are inherent in memory. Where in this critical thinking makes students able to solve problems in learning by using cognitive or reason. 


\section{References}

Ary, Donald, Jacobs, L. C. and Razavieh, Asghar. (2011). Pengantar Penelitian dalamPendidikan, Terjemahan Arief Furchan. Yogyakarta: Pustaka Pelajar.ctober 20

Dwiyogo. (2018).Pembelajaran Berbasis Blended Learning. Depok: Rajawali Pers.

Fisher, Alec. (2009). Berpikir Kritis Sebuah Pengantar. Jakarta: Erlangga.

Fuad, N, M, et al. 2017. Improving Junior High Schools' Critical Thinking Skills Basedon Test Three Different Models of Learning. International Journal of Instruction. Vol. 10, No. 1.

Hamruni. (2012). Strategi Pembelajaran. Yogyakarta: Insan Madani.

Jhonson, Elaine B. (2012). CTL: Contextual Teaching \& Learning Menjdikan Kegiatan Belajar-Mengajar Mengasyikkan dan Bermutu. Bandung: Mizan Media Utama.

Mukmin, B. A., et al. (2019). Citizenship Politics (Reviewing the Meaning of Democracy in Majanggut I Village, Royal District Pakpak Barat Regency). Budapest International Research and Critics Institute-Journal (BIRCI-Journal), 354-362.

Nasution, S. (2010). Kurikulum dan Pengajaran. Jakarta: Bumi Aksara.

Panggabean, R.H.,et al. (2019). Student Learning Result of Citizenship Education in Internet Learning Media with High Interpersonal Communication in High School Al-Azhar Medan. Budapest International Research and Critics in Linguistics and Education (BirLE) Journal, 491-498.

Rangkuti, A. N. and Hasibuan, W. S. (2019). Learning of Spatial Operations in 1st Grade of Junior High School (MTs.S NU Paringgonan) Ulu Barumun Sub-district Padang Lawas Regency. Budapest International Research in Linguistics and Education Sciences (BirLE) Journal. 2(1): 181-193.

Rusman. (2016). Model-model Pembelajaran: Mengembangkan Profesionalisme Guru Edisi Kedua. Jakarta: Rajawali Press.

Rusman. (2018). Belajar dan Pembelajaran Berbasis Komputer. Bandung: Alfabeta.

Sani, R. A. (2018). Pembelajaran Berbasis HOTS (Higher Order Thinking Skills). Jakarta: Tira Smart.

Sanjaya, W. (2011). Strategi Pembelajaran Berorientasi Standar Proses Pendidikan. Jakarta: Kencana.

Setiawan, D, dan Setiawan, F. (2014). Pendidikan Karakter dalam Perspektif Kewarganegaraan. Medan. LARISPA.

Shoimin, A. (2018). 68 Model Pembelajaran Inovatif dalam Kurikulum 2013. Yogyakarta: AR-RUZZ MEDIA.

Slameto. (2010). Belajar \& Faktor-faktor yang Mempengaruhi. Jakarta: Rineka Cipta.

Slavin, R. E. (2016). Cooperative Learning Teori, Riset dan Praktik. Bandung: Nusa Media.

Sudana, P. A., dan Wesnawa, G.A. (2017). Penerapan Model PembelajaranKooperatifTipe STAD untuk Meningkatkan Hasil Belajar IPA. Jurnal Ilmiah Sekolah Dasar. Vol.1 No.1.

Surip, M. (2017).Berpikir Kritis Analisis Kajian Filsafat Ilmu. Jakarta: Halaman Moeka. 